University of New Hampshire

University of New Hampshire Scholars' Repository

$5-22-2002$

\title{
Hypsometry and Volume of the Arctic Ocean and Its Constituent Seas
}

Martin Jakobsson

Follow this and additional works at: https://scholars.unh.edu/ccom

Part of the Oceanography and Atmospheric Sciences and Meteorology Commons

\section{Recommended Citation}

Jakobsson, M., Hypsometry and volume of the Arctic Ocean and its constituent seas, Geochem. Geophys. Geosyst., 3(5), 10.1029/2001GC000302, 2002.

This Journal Article is brought to you for free and open access by the Center for Coastal and Ocean Mapping at University of New Hampshire Scholars' Repository. It has been accepted for inclusion in Center for Coastal and Ocean Mapping by an authorized administrator of University of New Hampshire Scholars' Repository. For more information, please contact Scholarly.Communication@unh.edu. 


\title{
Correction published 13 February 2004
}

\section{Hypsometry and volume of the Arctic Ocean and its constituent seas}

\author{
Martin Jakobsson \\ Center for Coastal and Ocean Mapping/Joint Hydrographic Center, University of New Hampshire, Durham, \\ New Hampshire 03824, USA (martin.jakobsson@unh.edu)
}

[1] This paper presents an analysis of the Arctic Ocean and its constituent seas for seafloor area distribution versus depth and ocean volume. The bathymetry from the International Bathymetric Chart of the Arctic Ocean (IBCAO) is used together with limits defining this ocean and its constituent seas from the International Hydrographic Organization (IHO) as well as redefined limits constructed to confine the seas to the shallow shelves. IBCAO is a bathymetric grid model with a resolution of $2.5 \times 2.5 \mathrm{~km}$, which significantly improved the portrayal of the Arctic Ocean seafloor through incorporation of newly released bathymetric data including echo soundings from U.S. and British navies, scientific nuclear submarine cruises, and icebreaker cruises. This analysis of seafloor area and ocean volume is the first for the Arctic Ocean based on this new and improved portrayal of the seafloor as represented by IBCAO. The seafloor area and volume are calculated for different depths starting from the present sea level and progressing in increments of $10 \mathrm{~m}$ to a depth of $500 \mathrm{~m}$ and in increments of $50 \mathrm{~m}$ from $550 \mathrm{~m}$ down to the deepest depth within each of the analyzed seas. Hypsometric curves expressed as simple histograms of the frequencies in different depth bins and depth plotted against cumulative area for each of the analyzed seas are presented. The area and volume calculations show that the entire IHO-defined Arctic Ocean makes up $\sim 4.3 \%$ of the total ocean area but only $\sim 1.4 \%$ of the volume. Furthermore, the IHO Arctic Ocean is the shallowest (mean depth $1201 \mathrm{~m}$ ) of all the major oceans and their adjacent seas. The continental shelf area, from the coasts out to the shelf break, make up as much as $\sim 52.9 \%$ of the total area in the Arctic Ocean, defined in this work as consisting of the oceanic deep Arctic Ocean Basin; the broad continental shelves of the Barents, Kara, Laptev, East Siberian, Chukchi, and Beaufort Seas; the White Sea; and the narrow continental shelf off both the Canadian Arctic Archipelago and northern Greenland. This result indicates that the Arctic Ocean has significantly larger continental shelves compared with all the other oceans, where previous studies show that the proportion of shelves, from the coasts out to the foot of the continental slopes, only ranges between about 9.1 and $17.7 \%$. Furthermore, the derived hypsometric curves show that most of the Arctic Ocean shelf seas besides the Barents Sea, Beaufort Sea, and the shelf off northern Greenland have a similar shape, with the largest seafloor area between 0 and $50 \mathrm{~m}$. The East Siberian and Laptev seas, in particular, show area distributions concentrated in this shallow depth range, and together with the Chukchi Sea they form a large flat shallow shelf province composing as much as $22 \%$ of the entire Arctic Ocean area but only $1 \%$ of the volume. This implies that the circulation in the Arctic Ocean might be very sensitive to eustatic sea level changes. One of the aims with this work is to make up-to-date high-resolution area and volume calculations for the Arctic Ocean at various depths available for download.

Components: 6384 words, 8 figures, 2 tables, 1 dataset, 1 video.

Keywords: Arctic Ocean; Hypsometry; Bathymetry; IBCAO; Arctic Ocean volume.

Index Terms: 4207 Oceanography: General: Arctic and Antarctic oceanography; 4283 Oceanography: General: Water masses; 9315 Information Related to Geographic Region: Arctic region; 3045 Marine Geology and Geophysics: Seafloor morphology and bottom photography. 
Received 5 January 2002; Revised 20 February 2002; Accepted 20 February 2002; Published 23 May 2002.

Jakobsson, M., Hypsometry and volume of the Arctic Ocean and its constituent seas, Geochem. Geophys. Geosyst., 3(5), 10.1029/2001GC000302, 2002.

\section{Introduction}

[2] Researchers have long been interested in Earth's hypsometry, the distribution of surface area at various elevations of land and depths of ocean. Menard and Smith [1966] published the first computer analysis of the hypsometry of the world ocean basin provinces, which provided a new perspective on large-scale seafloor morphology. In addition, they calculated the volumes of the world oceans and provided values that have been widely cited. Their study was based on the most recent, at the time, American and Russian bathymetric charts. The least known of their studied regions was the Arctic Ocean, where the information used was from the Tectonic Chart of the Arctic Ocean published in 1963 by the Geological Institute in Moscow [Pusharovsky, 1963]. Logistical constraints in the central Arctic Ocean, with its thick perennial sea ice cover, have largely prevented the efficient collection of geological and geophysical data in areas of interest until recently, when modern icebreakers have penetrated the pack ice. In addition, nuclear submarines have collected geophysical data over large areas under the pack ice, substantially increasing the database. Analyses of this recent data have answered many questions about the history and evolution of the Arctic Ocean Basin and have changed our understanding of seafloor morphology.

[3] During the spring of 2000 a Beta version of the International Bathymetric Chart of the Arctic Ocean (IBCAO) was released [Jakobsson et al., 2000]. IBCAO is a grid model with a resolution of $2.5 \times 2.5 \mathrm{~km}$ that has significantly improved the portrayal of the Arctic Ocean seafloor because of the large amount of bathymetric data that was released just prior to its compilation. This data included echo soundings from U.S. and British navies nuclear submarine cruises between 1958 and 1988, echo soundings from nuclear submarine cruises from the Scientific Ice Exploration (SCICEX) program 1993-1999, and echo soundings from icebreaker cruises carried out by Canada, Germany, Sweden, and the United States. In addition, bathymetric contour maps were used for the IBCAO compilation in areas where original depth measurements were not available. This includes the new bathymetric map published by the Head Department of Navigation and Oceanography (HDNO) et al. [1999]. Many of these new bathymetric data sets covered areas of the Arctic where previously published bathymetric charts were based only on a few sparse track lines.

[4] In this study, the hypsometry and volume of the Arctic Ocean and its constituent seas have been estimated from IBCAO version 1.0 [Jakobsson et al., 2001], supplemented in some small southern areas by Global Seafloor Topography derived from satellite altimetry and ship soundings [Smith and Sandwell, 1997]. In order to analyze these properties we need boundaries defining the exact limits for the Arctic Ocean and its constituent seas. The International Hydrographic Organization (IHO) has formally defined oceans and seas, and on the basis of their publication S-23 [International Hydrographic Organization (IHO), 2001] (Figure 1) the seafloor area and ocean volume of the Arctic Ocean and constituent seas were initially calculated. The results based on the IHO-defined Arctic Ocean are only briefly discussed since the main part of this work has focused on a more restricted definition of the Arctic Ocean consisting of the almost landlocked ocean including the oceanic deep Arctic Ocean Basin; the broad continental shelves of the Barents, Kara, Laptev, East Siberian, Chukchi, and Beaufort Seas; the White Sea; and the narrow continental shelf off both the Canadian Arctic Archipelago and northern Greenland (Figure 2). This definition is hereinafter referred to as the 

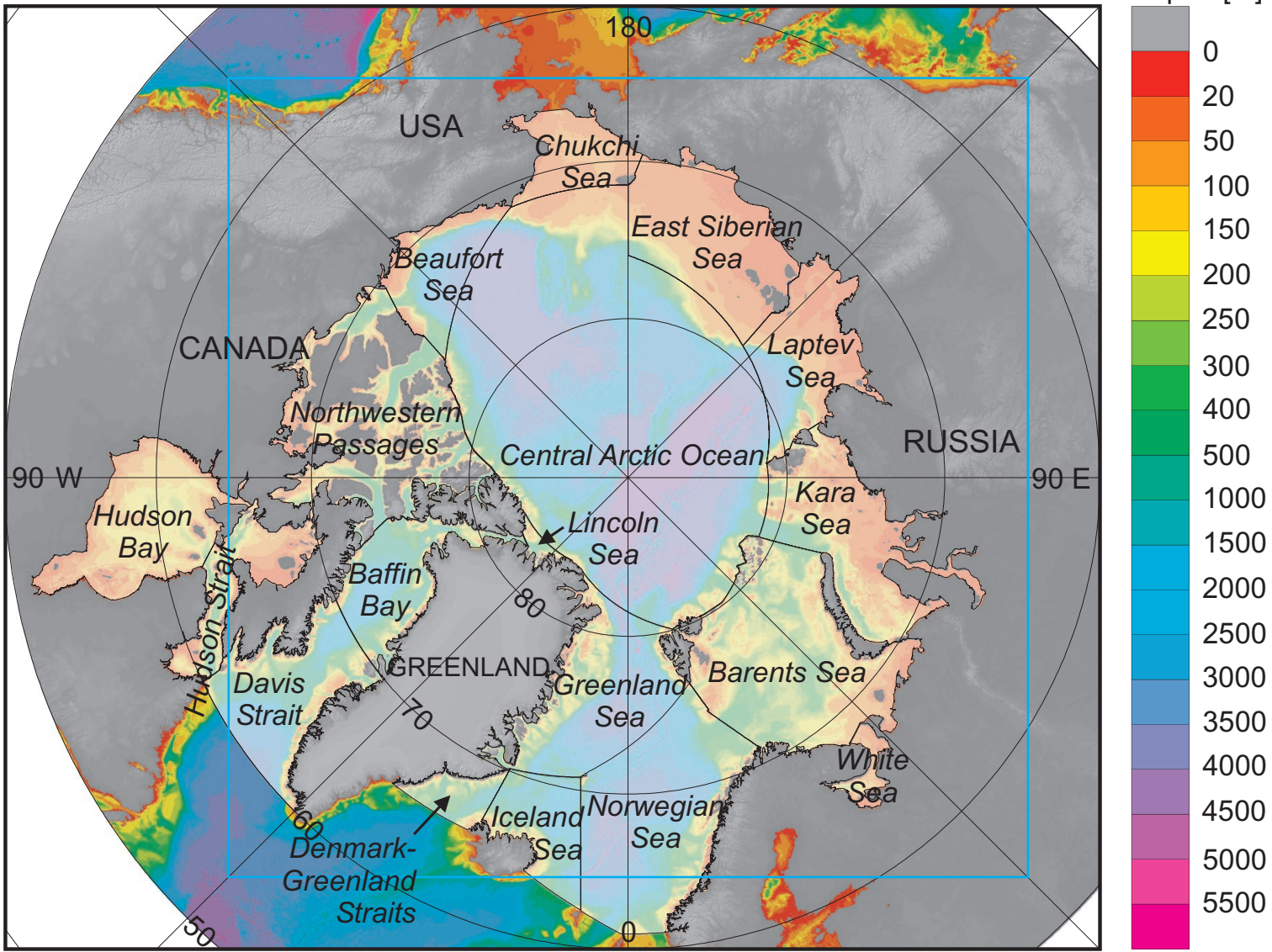

Figure 1. Overview map showing the International Hydrographic Organization (IHO)-defined limit of the Arctic Ocean (lighter, semitransparent shading) and its constituent seas. The blue rectangle shows the cover of the International Bathymetric Chart of the Arctic Ocean (IBCAO) model. Outside the cover of the IBCAO model the global seafloor topography from satellite altimetry [Smith and Sandwell, 1997, version 8.2] was used (see the text for description of combining these two data sets).

Arctic Ocean, while the IHO definition is referred to as the IHO Arctic Ocean. The ocean and sea limits in the IHO publication S-23 are constructed by rhumb lines connecting defined points with given positions and coastlines, and thus the outlined seas do not necessarily enclose physiographic provinces such as, for example, the shallow shelves. Therefore, in order to calculate the area and water mass volume of the Arctic Ocean shelf, the definitions of the seas have been modified by constructing limits that traced the continental shelf break so that each sea around the central Arctic Ocean Basin was made into a shallow shelf sea.

[5] The region here referred to as the Arctic Ocean closely conforms to one of the regions studied by
Menard and Smith [1966], making it possible to draw a comparison with the historical results. Hypsometric curves and volume calculations are presented for each constituent sea and are available in the supplemental data so the reader may derive, for example, the volume of a water mass at a particular depth interval that is relevant to a specific oceanographic line of inquiry.

\section{Methods}

\subsection{Grid Projection}

[6] The IBCAO grid currently exists in two versions: (1) a Cartesian grid with a cell spacing of $2.5 \times 2.5 \mathrm{~km}$ on a Polar Stereographic projection 

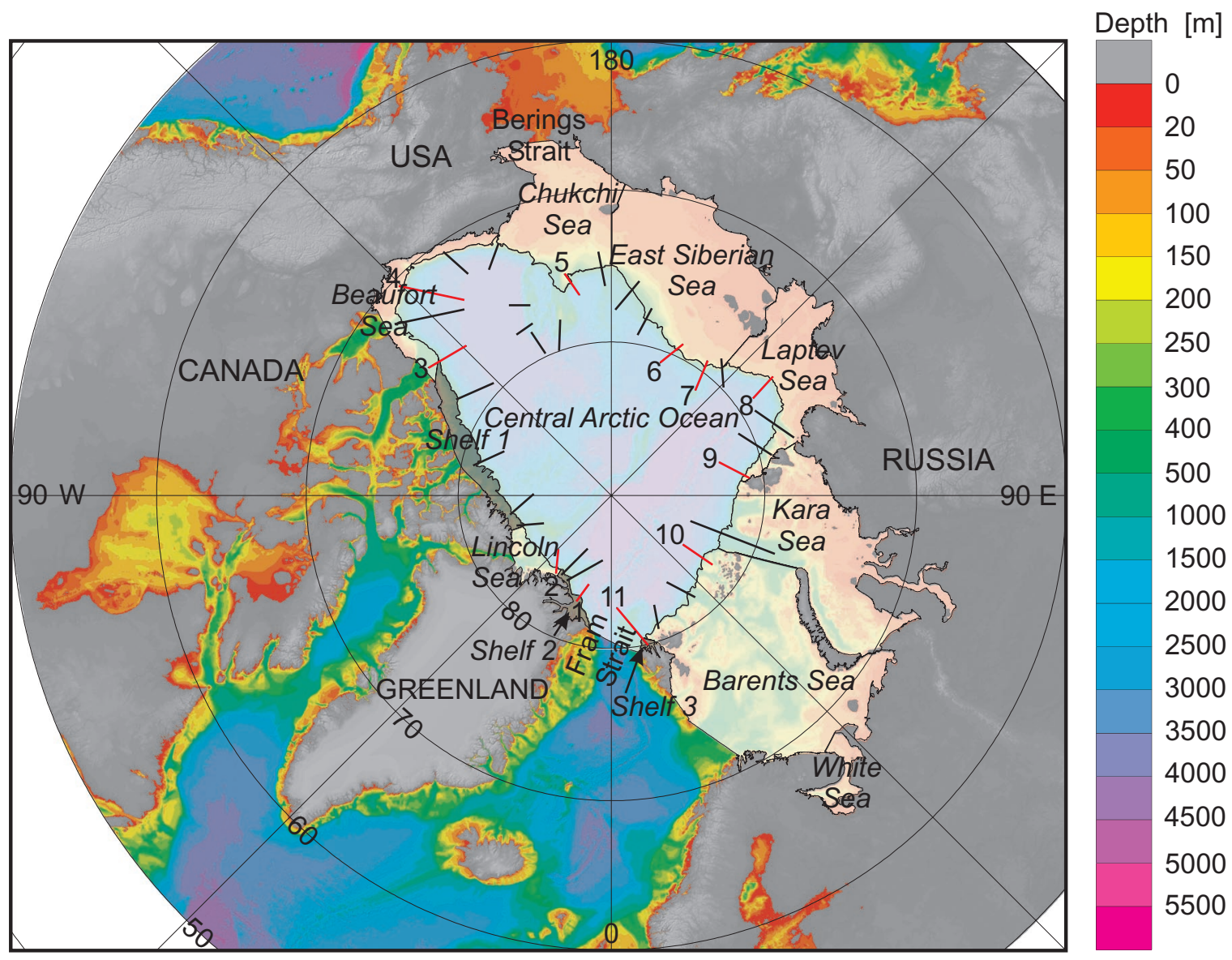

Figure 2. Overview map showing the ocean area referred to here as the Arctic Ocean (lighter, semitransparent shading), upon which this work is focused. The constituent seas' limits within this area have been modified from the original IHO definitions to better reflect the shallow shelves as physiographic provinces. Three areas of the continental shelf were not naturally included into the redefined IHO seas and were therefore made into new regions simply referred to as shelves 1-3 (shaded slightly darker). The black and red lines indicate bathymetric profiles that were used as checks in the process of delineating the shelf break from a slope model. The shelf break serves as the seaward limit of the redefined Arctic Ocean constituent seas. The bathymetric profiles marked in red are shown in Figure 3 as examples illustrating the variation of the Arctic Ocean continental slope and the location of the shelf break.

with true scale at $75^{\circ} \mathrm{N}$ and (2) a geographic grid with a cell spacing of $1 \mathrm{~min}$. The coordinates in both versions refer to the World Geodetic System 1984 (WGS 84) datum. In this study, the Polar stereographic version was preferred because of its superior representation of the bathymetry at higher latitudes. To obtain valid area and volume calculations, the Polar Stereographic grid had first to be reprojected to a Lambert Equal Area projection. This was done using Z/I Imaging's tool Modular GIS Environment (MGE) Terrain Analyst (MTA). MGE Terrain Analyst is the terrain modeling solution in Intergraph's MGE family of software applications (for further information about these computer programs see Z/I imaging (http://www.ziimaging.com/) and Intergraph (http://www.intergraph.com/) web pages). The coverage of the transformed grid is shown in Figure 1.

\subsection{Combining IBCAO With Global Seafloor Topography From Satellite Altimetry and Ship Soundings}

[7] As defined by IHO, the Arctic Ocean extends south of $64^{\circ}$, beyond the normal IBCAO coverage 
(Figure 1). Major portions of Hudson Bay and Hudson Strait and small parts of the Northwestern Passages, Davis Strait, Iceland Sea, and Norwegian Sea thus fell outside the IBCAO coverage. Therefore it was necessary to retrieve information about the seafloor topography in these regions from another model. The global seafloor topography from satellite altimetry and ship soundings [Smith and Sandwell, 1997, version 8.2] was chosen for this purpose. Smith and Sandwell [1997] show that a fairly large number of ship soundings were used to constrain their algorithm for prediction of seafloor topography in those areas of the Arctic falling outside the IBCAO coverage (see www.ngdc.noaa.gov/mgg/ bathymetry/predicted/predicted_images.html). This justifies the use here of their data set for volume and area calculations. The global seafloor topography gridded data set was constructed on a Mercator projection assuming a spherical Earth, and it had to be transformed to the WGS 84 datum and projected to Lamberts Equal Area to be combined properly with the IBCAO grid.

[8] The following scheme was used for this process:

1. The individual coordinates in the Global Seafloor Topography grid were unprojected to latitude and longitude coordinates using tools in the Generic Mapping Tools (GMT) software package [Wessel and Smith, 1991].

2. The depth values, with latitude and longitude coordinates from the global seafloor topography grid, were brought into MGE and datum transformed to WGS 84 using a Molodesky standard datum transformation algorithm and subsequently projected to Lamberts Equal Area using MGE tools.

3. The projected Lamberts Equal Area coordinates were gridded using MTA. A triangulation model, using Delaunay triangulation, was initially computed, and from this model the grid $(2.5 \times 2.5$ $\mathrm{m})$ was interpolated using a planar interpolation.

4. The global seafloor topography above $50^{\circ} \mathrm{N}$, now with a Lamberts Equal Area projection on WGS 84, was merged to the IBCAO grid along the outer limit of the IBCAO grid coverage using a feathering technique averaging over an area of four grid cells to smooth the transition between the two models. The final result is shown in Figure 1.

\subsection{Defining the Limits of the Arctic Ocean Constituent Seas}

[9] $I H O$ [2001] describes each of the world oceans and seas by positions of fix points that are connected either by rhumb lines or by a coastline. With this information, topologically clean areas for the IHO Arctic Ocean constituent seas were constructed suitable for the initial geographic information systems (GIS) analyses (Figure 1). The world vector shoreline (WVS) [Soluri and Woodson, 1990] (the recently released updated WVS Plus was used) at a scale of 1:3,000,000 was used to represent the coastline.

[10] As mentioned in section 1, the main part of this work is focused on an Arctic Ocean constrained by the Fram Strait, the western limit of Barents Sea, the Bering Strait, and the Canadian Arctic Archipelago (Figure 2). To be able to analyze the volume and area of shallow shelves of this Arctic Ocean and compare the results with the deep portions, the IHO subdivisions were slightly modified prior to the calculations (Figure 2). The changes are as follows: To construct the northern limits of Barents, Laptev, Kara, East Siberian, Chukchi, Beaufort, and Lincoln Seas, the shelf break has been used as the outermost limits of these seas. The shelf break is here defined as the seaward extension of the continental margin along which there is a marked increase of slope. The limit at the Fram Strait goes from the northeastern point of Greenland to the northwestern point of Spitsbergen, which implies that a small part of the IHOdefined Greenland Sea is included here into the central Arctic Ocean. The central Arctic Ocean is now defined as the area enclosed by the shallow surrounding continental shelf seas. However, there are three areas on the continental shelf (two of them previously belonging to the Greenland Sea) that are not included into any of the redefined shallow shelf seas. These three areas are separated from a deep central Arctic Ocean and treated separately (Figure 2). A slope model constructed from the IBCAO grid by equations (1) and (2) was used to carry out the delineation of the shelf break together with additional bathymetric profiles (Figures 2 and 3). The use of a 


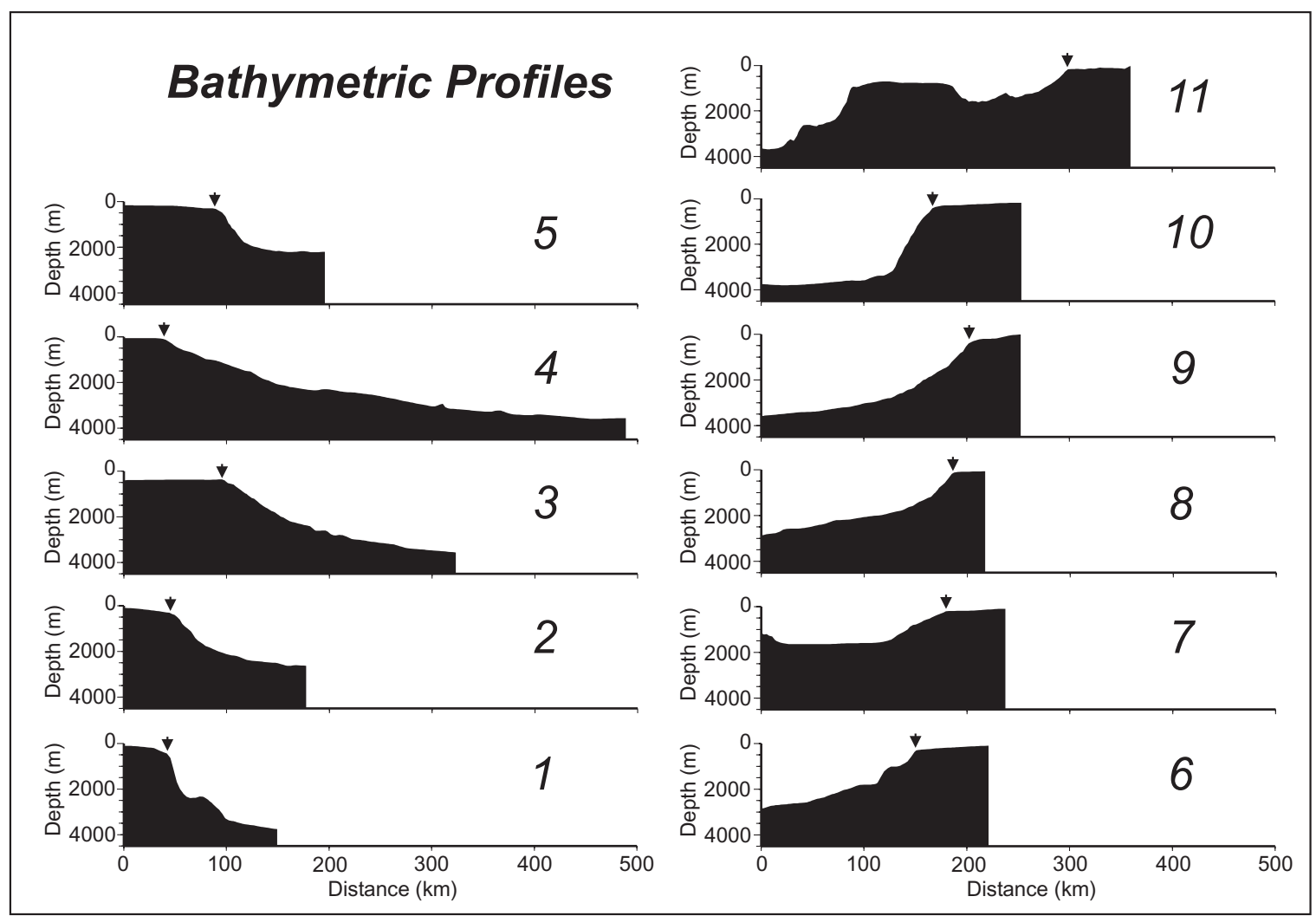

Figure 3. Bathymetric profiles that were used together with a slope model in the process of delineating the shelf break. The locations of these profiles are shown in Figure 2. The arrow in each profile indicates the defined shelf break.

slope model proved to be very efficient for an initial delineation of the Arctic Ocean shallow shelf areas (M. Jakobsson et al., unpublished data, 2002).

$$
\begin{gathered}
G(x, y)=\|\nabla z(x, y)\|=\sqrt{\left(\frac{\partial z(x, y)}{\partial x}\right)^{2}+\left(\frac{\partial z(x, y)}{\partial y}\right)^{2}}, \\
\text { SLOPE }=\arctan (G(x, z)),
\end{gathered}
$$

where $G$ is maximum gradient.

\subsection{Volume and Area Calculations}

[11] Area and volume calculations have been carried out using MTA batch tools on a Triangulated Irregular Networks (TIN) model of the merged IBCAO and Global Seafloor Topography. This TIN model was simply constructed by Delaunay triangulation of the grid model. The idea for using a TIN model rather than a grid model for these calculations was to be able to estimate the "true" surface area of the topography in addition to the projected planar surface area. However, the results showed that since the TIN model is derived from the regular IBCAO grid, the difference between calculated surface area and planar projected area for each sea is insignificant.

[12] The volume and area of each of the Arctic Ocean seas were calculated within the constructed polygons defining the seas (both within the IHO original limits and the redefined limits) by inserting a plane and calculating the volume and area below the plane. This plane was lowered in increments of $10 \mathrm{~m}$ from $0 \mathrm{~m}$ to a depth of $500 \mathrm{~m}$ and in increments of $50 \mathrm{~m}$ from $550 \mathrm{~m}$ down to the deepest depth within the enclosed polygon. Animation 1, made using output from the threedimensional visualization and analyzing software "Fledermaus" [Mayer et al., 2000], illustrates how the area and volume calculations were carried 
a)

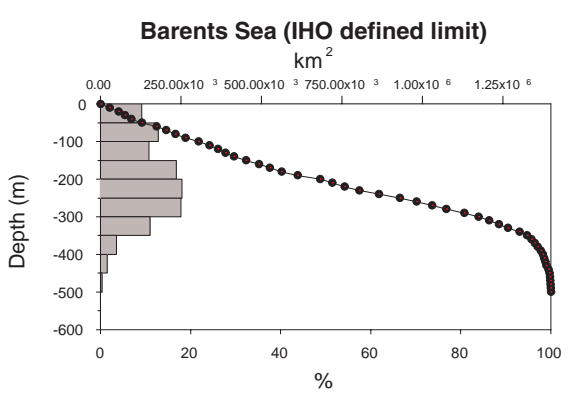

White Sea (IHO defined limit)

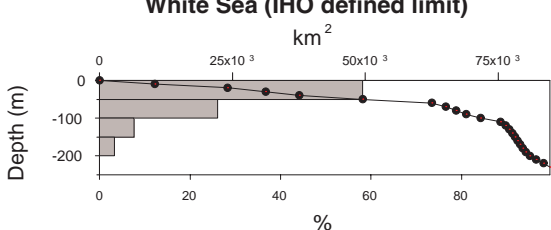

Kara Sea (IHO defined limit)

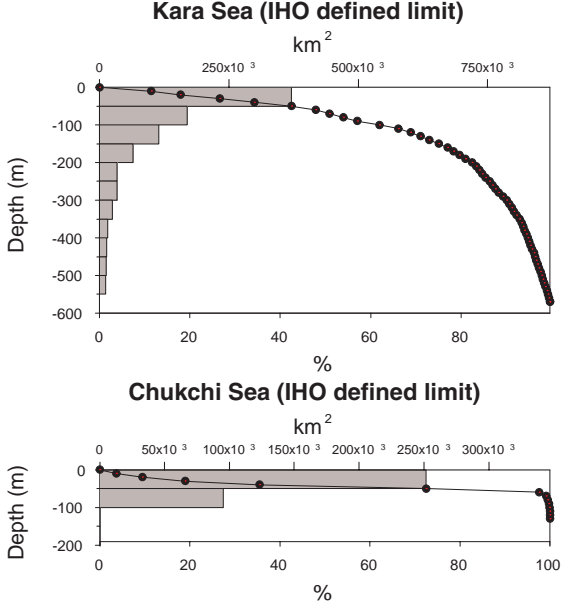

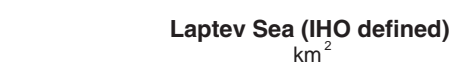

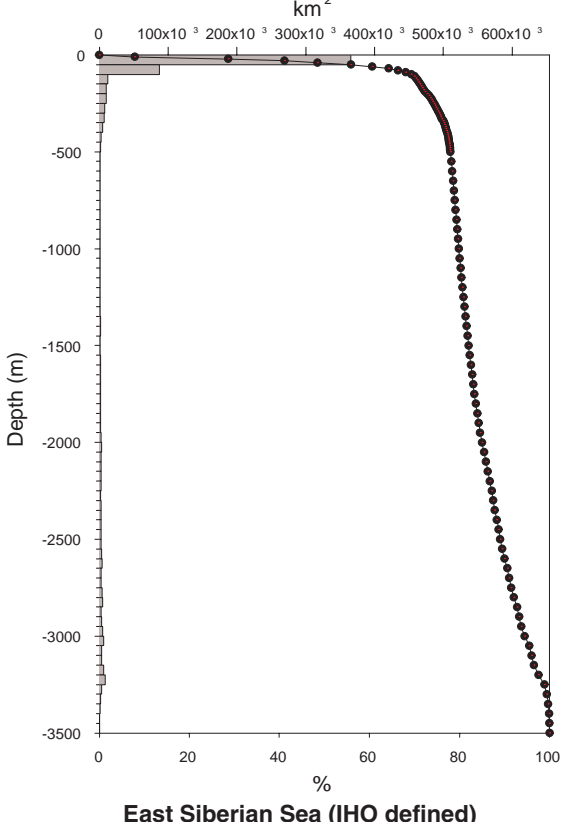

East Siberian Sea (IHO defined)

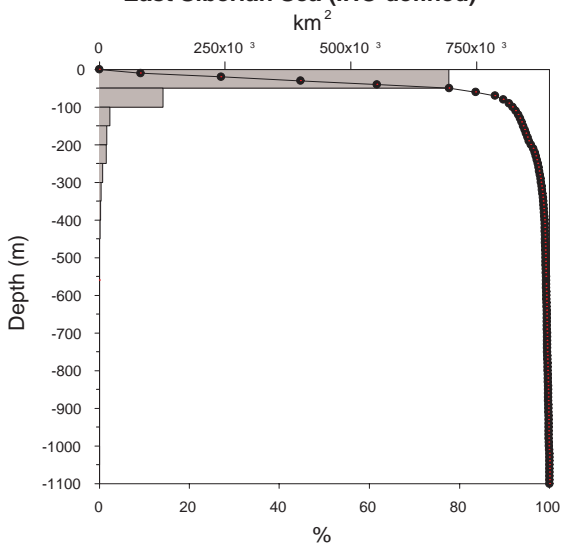

Figure 4. Hypsometry calculated at $50 \mathrm{~m}$ depth intervals (shown as bars) for the IHO-defined Arctic Ocean seas. The plotted curves show the seafloor surface area (in square kilometers on the upper $x$ axis and in accumulative percent on the lower $x$ axis) above the depth indicated on the $y$ axis. This means that each of the defined seas will get the maximum seafloor area at its deepest depth. Observe that the scale on the depth axis is different for the seas with depths exceeding $1500 \mathrm{~m}$.

out with the IHO-defined Greenland Sea as an example.

\section{Results and Discussion}

\subsection{Hypsometry and Volumes of IHO-Defined Arctic Ocean and Its Constituent Seas}

[13] Hypsometric curves expressed as a simple histogram of the frequencies in $50 \mathrm{~m}$ depth bins and depth plotted against cumulative area for each of the IHO-defined Arctic seas are shown in Figure 4, and the results from the volume calculations are summarized in Figure 5a. It is clearly seen in the hypsometric curves that the IHO definitions of the constituent seas are not strictly confined to the shelf areas and, in some cases, extend out into the deep central Arctic Basin (see, for example, the Laptev Sea, Figure 4). Figure 6a and Table 1 show the area and volume of each of the Arctic Ocean seas at mean sea level, calculated with the plane, described above, at $0 \mathrm{~m}$. A spreadsheet included in the supplemental data with the 

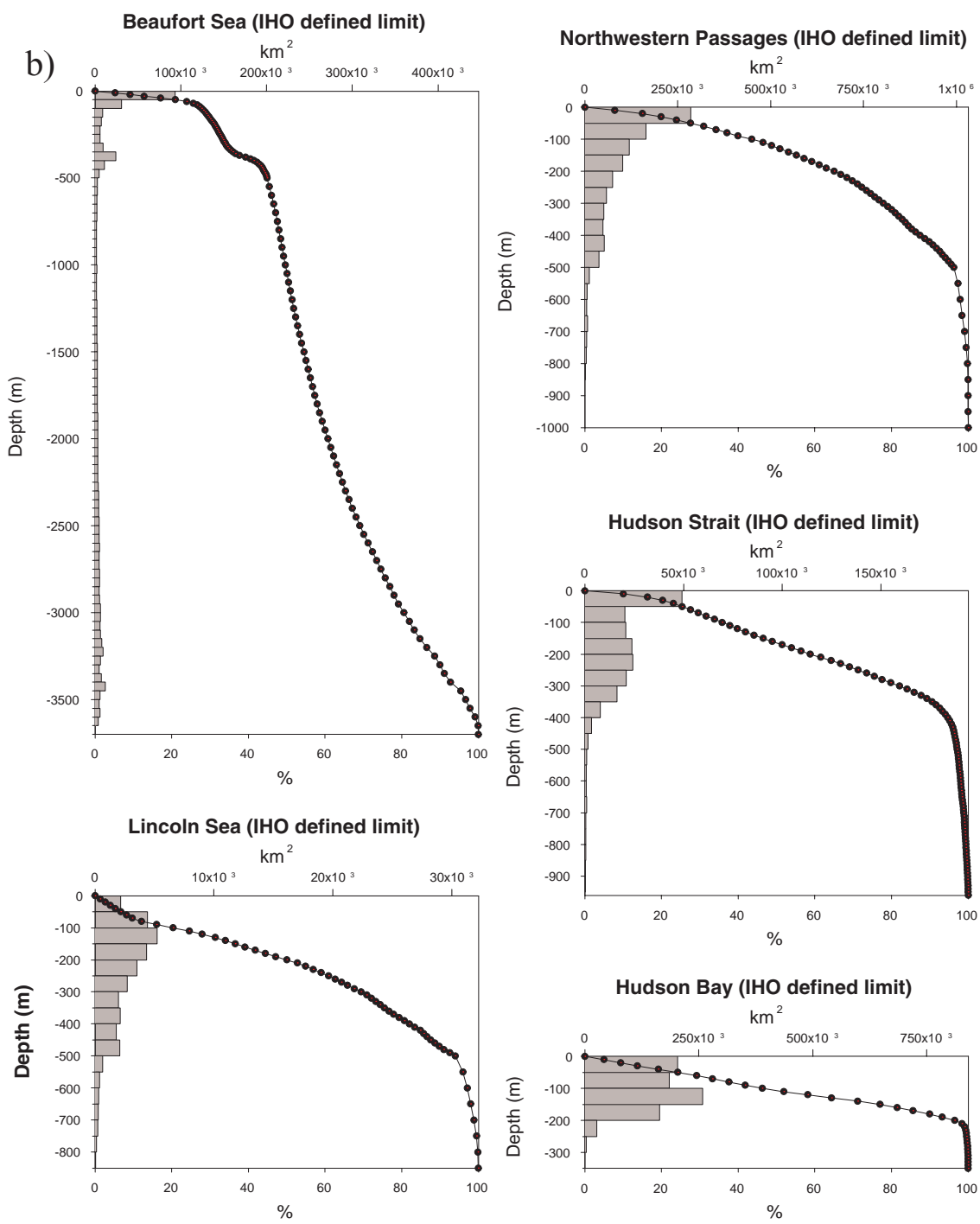

Figure 4. (continued)

result from the calculations at each depth interval is available so that the reader can derive volumes of particular depth intervals, possibly representing a water mass as of interest.

[14] By using Menard and Smith's [1966] estimation of the entire world ocean area and volume and the results derived here, it is possible to calculate the IHO-defined Arctic Ocean's portion of the entire world oceans as $\sim 4.3 \%$ of the total ocean area and only $\sim 1.4 \%$ of the volume. Menard and Smith's area and volume estimation of the entire Arctic Ocean differs from the one based on the IHO definitions presented here, mainly owing to their different definition of the Arctic Ocean (see Figure
1 of Menard and Smith [1966]). With a mean depth of $1201 \mathrm{~m}$, the IHO Arctic Ocean is the shallowest of all the major oceans and their adjacent seas (Table 1). Aside from the central deep basin, the Barents Sea has the largest area, closely followed by the Norwegian Sea, which in turn has the greatest volume and thus the deepest mean depth (1816 m) (Figure 6a and Table 1).

[15] The computed areas, volumes, and depth distributions of the IHO-defined Arctic Ocean seas are of limited value for geologic or oceanographic studies in as much as they do not represent physiographic regions. For example, using the IHO definitions, the area of the continental shelves cannot 

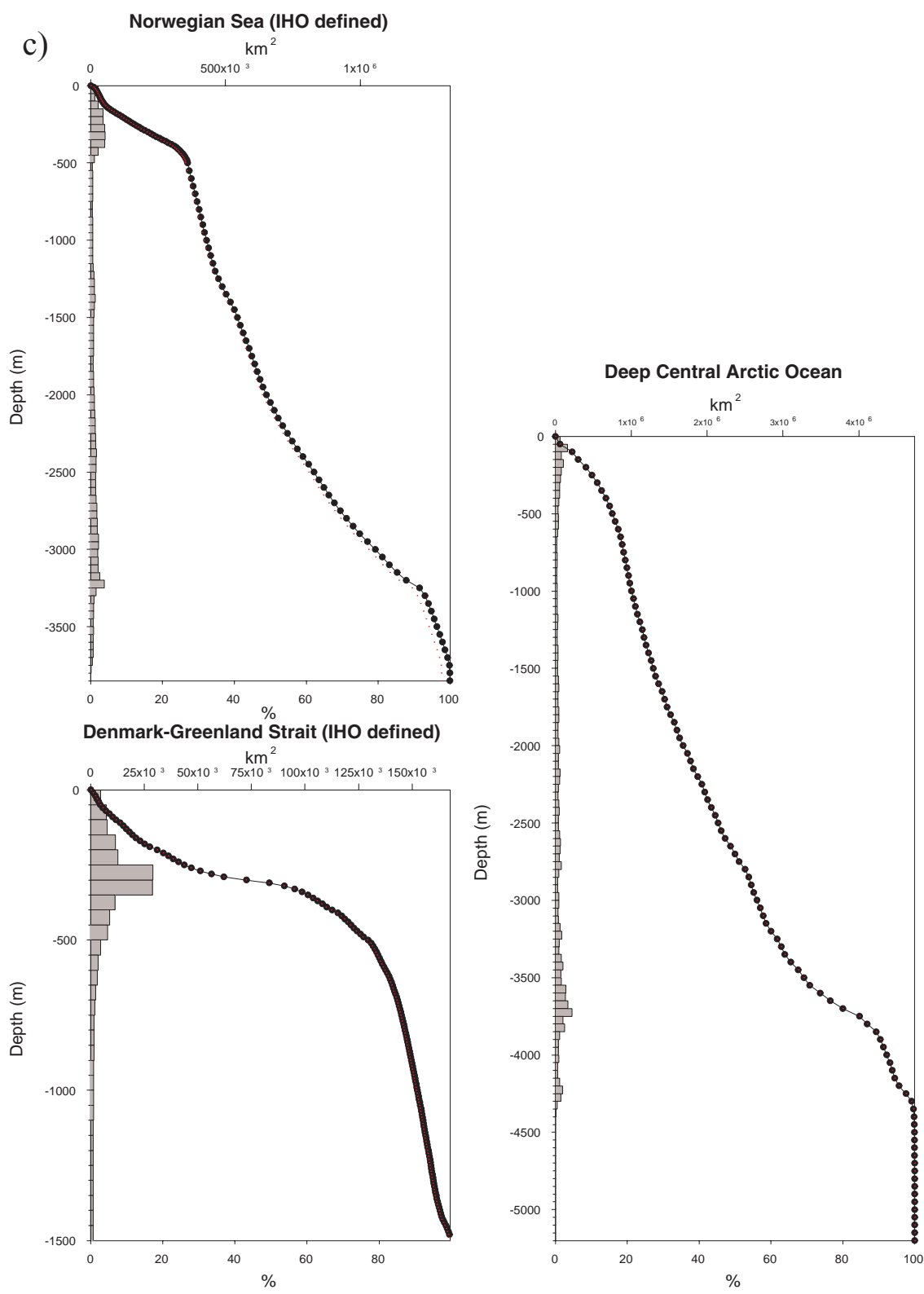

Figure 4. (continued)

be compared with the area of the deep ocean basins. Therefore the emphasis in this work has been to analyze the areas represented by the modified limits for the Arctic Ocean's constituent seas.

\subsection{Hypsometry and Volumes of the Arctic Ocean and Its Redefined Constituent Seas}

[16] The hypsometric curves for each of the redefined seas in the Arctic Ocean (Figure 2) are plotted in Figure 7, and the results from the volume calculations are summarized in Figure $5 \mathrm{~b}$. Figure $6 \mathrm{~b}$ and Table 2 present the volume and mean depth of each of the redefined Arctic Ocean seas in the same way Figure $6 \mathrm{a}$ and Table 1 present these properties for the IHO-defined seas. Furthermore, the supplemental data also includes the results from these calculations. The defined Arctic Ocean in Figure 2 conforms closely to one of Menard and Smith's [1966] two analyzed regions of the Arctic, which makes it possible to make some comparisons. The area estimation in this work (Table 2) is only $\sim 0.6 \%$ larger than theirs for the comparable 

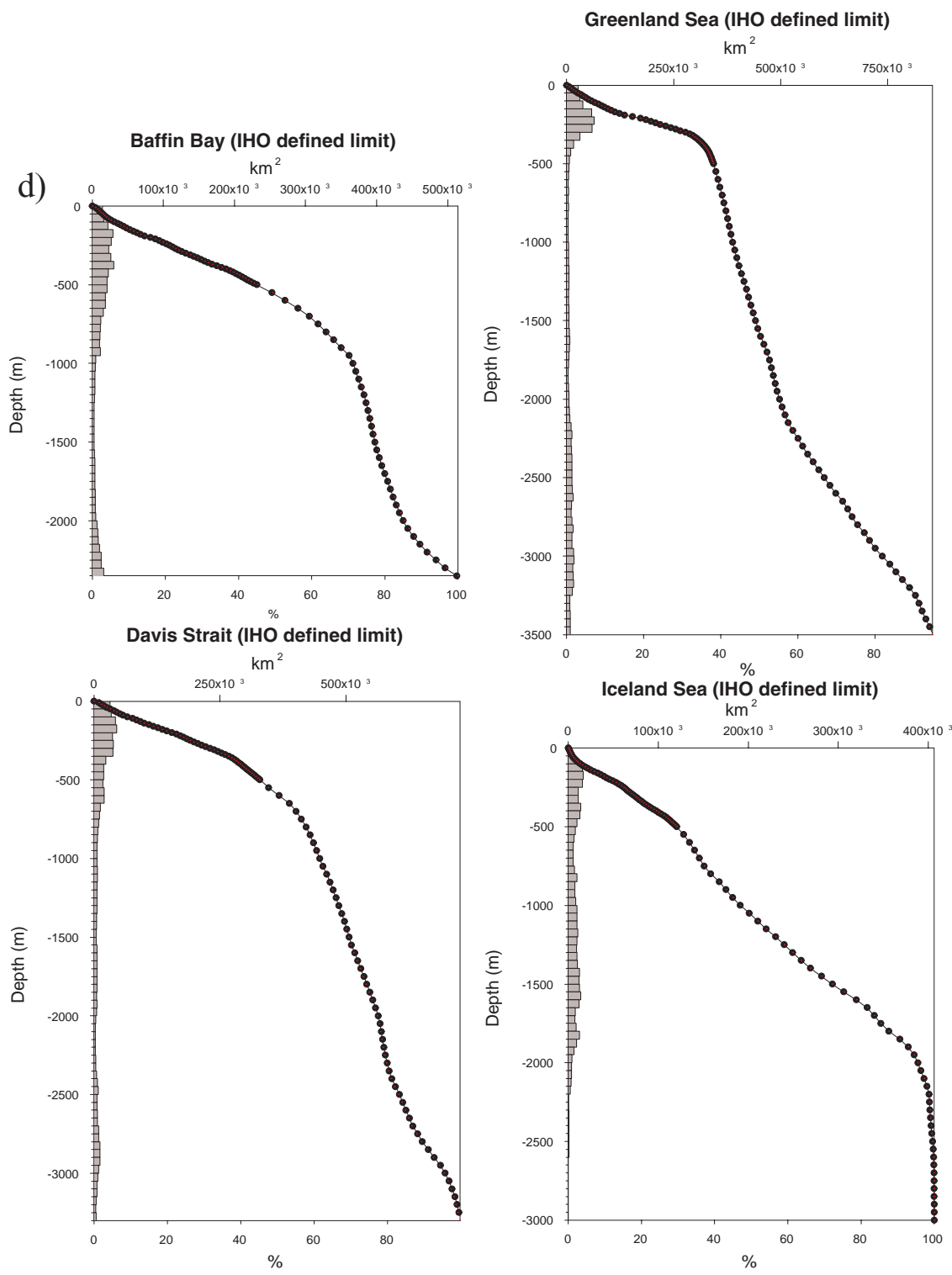

Figure 4. (continued)

region, which is remarkably close considering the difference in techniques of calculation and a slightly different definition of the limit near the Fram Strait. However, the volume estimated from the IBCAO data set is $\sim 2.9 \%$ larger than their computed volume, which cannot be explained solely by the difference in area estimation since this area difference would be located mainly on the shallow shelves. This means that the new data incorporated into IBCAO shows a generally deeper Arctic Ocean; the mean depth is estimated to be 1361 m compared with Menard and Smith's esti- mation of $1330 \mathrm{~m}$. The deepest depth in this portion of the IBCAO grid is approximately $5243 \mathrm{~m}$, located in the Gakkel Ridge axial valley close to the Laptev Sea margin (Figure 8). Note that this given depth is derived from the interpolated grid rather than a direct observation. At this location, IBCAO is based on information from the new bathymetric map published by the HDNO et al. [1999], which indicates a depth of $5260 \mathrm{~m}$.

[17] The Barents Sea is, after redefinition, slightly larger than the IHO-defined size since it has been 

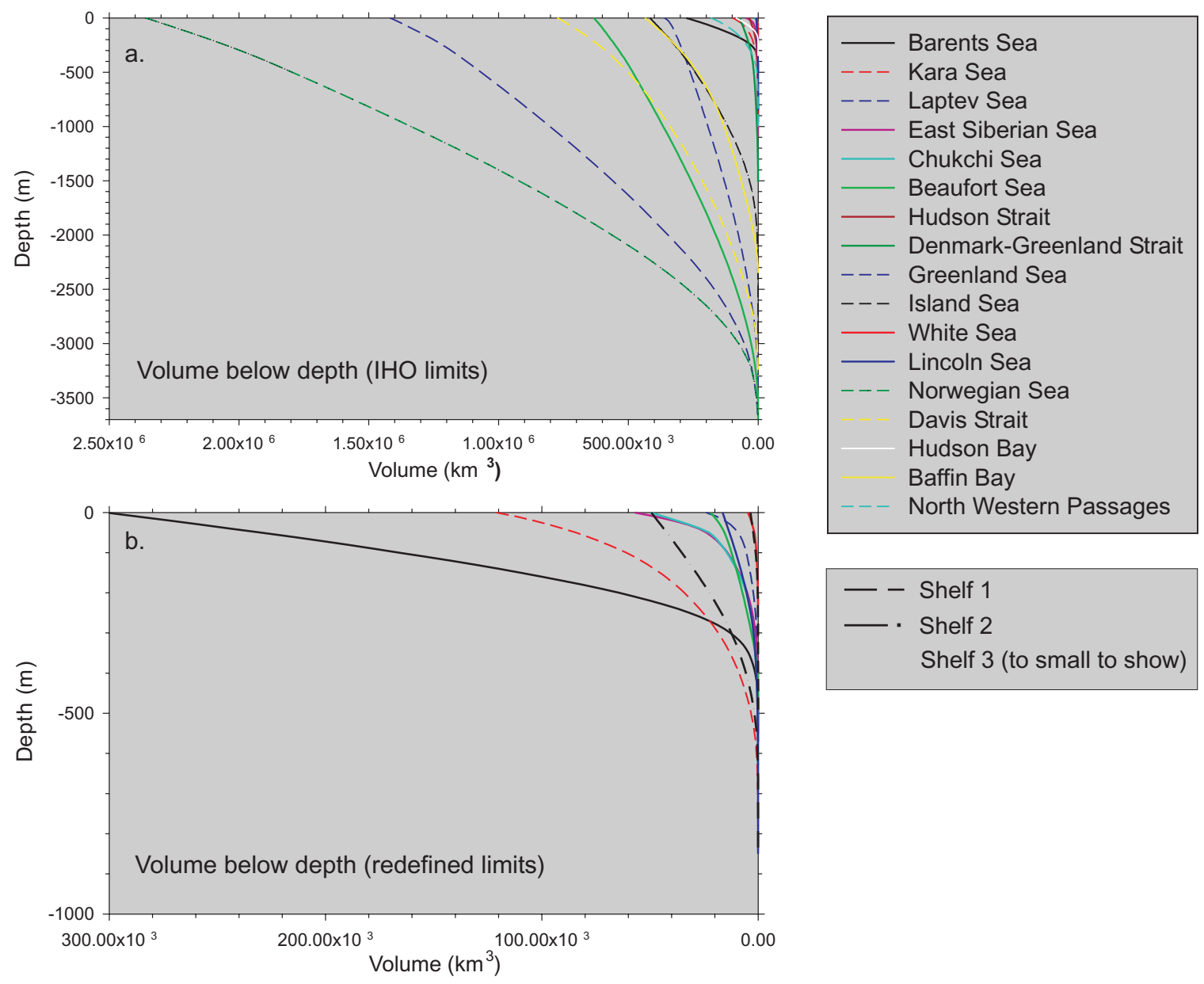

Figure 5. (a) A comparison of water volumes between the IHO-defined Arctic Ocean seas. Figure 5a shows volume below the depth indicated on the $y$ axis. The smaller seas in terms of volume are difficult to see in the plot because of the scale. However, Table 1 shows their maximum volumes, and for more detailed information the reader is referred to the supplemental data. (b) A comparison of water volumes between the redefined seas in the Arctic Ocean. Figure 5b shows volume below the depth indicated on the $y$ axis. The smaller seas in terms of volume are difficult to see in the plot due to the scale. However, Table 2 shows their maximum volumes, and for more detailed information the reader is referred to the supplemental data.

extended from Svalbard and the Frantz Josef Land Archipelago out to the shelf break. The mean depth is $\sim 200 \mathrm{~m}$, and the largest seafloor area is located between 150 and $300 \mathrm{~m}$ (Table 2 and Figure 7). Looking at the other histograms in Figure 7, all the redefined Arctic shelf seas besides Barents, Beaufort, and Lincoln Seas and shelf 2 show a similar shape of the hypsometric curve with the largest seafloor area between 0 and $50 \mathrm{~m}$. The hypsometry histograms for East Siberian and Laptev Seas, in particular, show area distributions significantly focused to this shallow depth range. They form, together with the Chukchi Sea, a large shallow shelf province with a very low seafloor relief and shallow mean depth (Table 2, Figures 7 and 8). This province accounts for as much as $22 \%$ of the entire Arctic Ocean area but only $1 \%$ of the volume. The Kara Sea is third largest in area, closely following the East Siberian Sea, but is the second largest in terms of volume. The hypsometry of the central basin reveals that the largest area consists of the deep ocean basins: the Canada, Makarov, Amundsen, and Nansen Basins (Figures 7 and 8).

[18] In the Arctic Ocean the continental shelf, from the coasts out to the shelf break, make up as much 


\section{a. Area and volumes of the Arctic Ocean constituent seas (IHO definitions)}

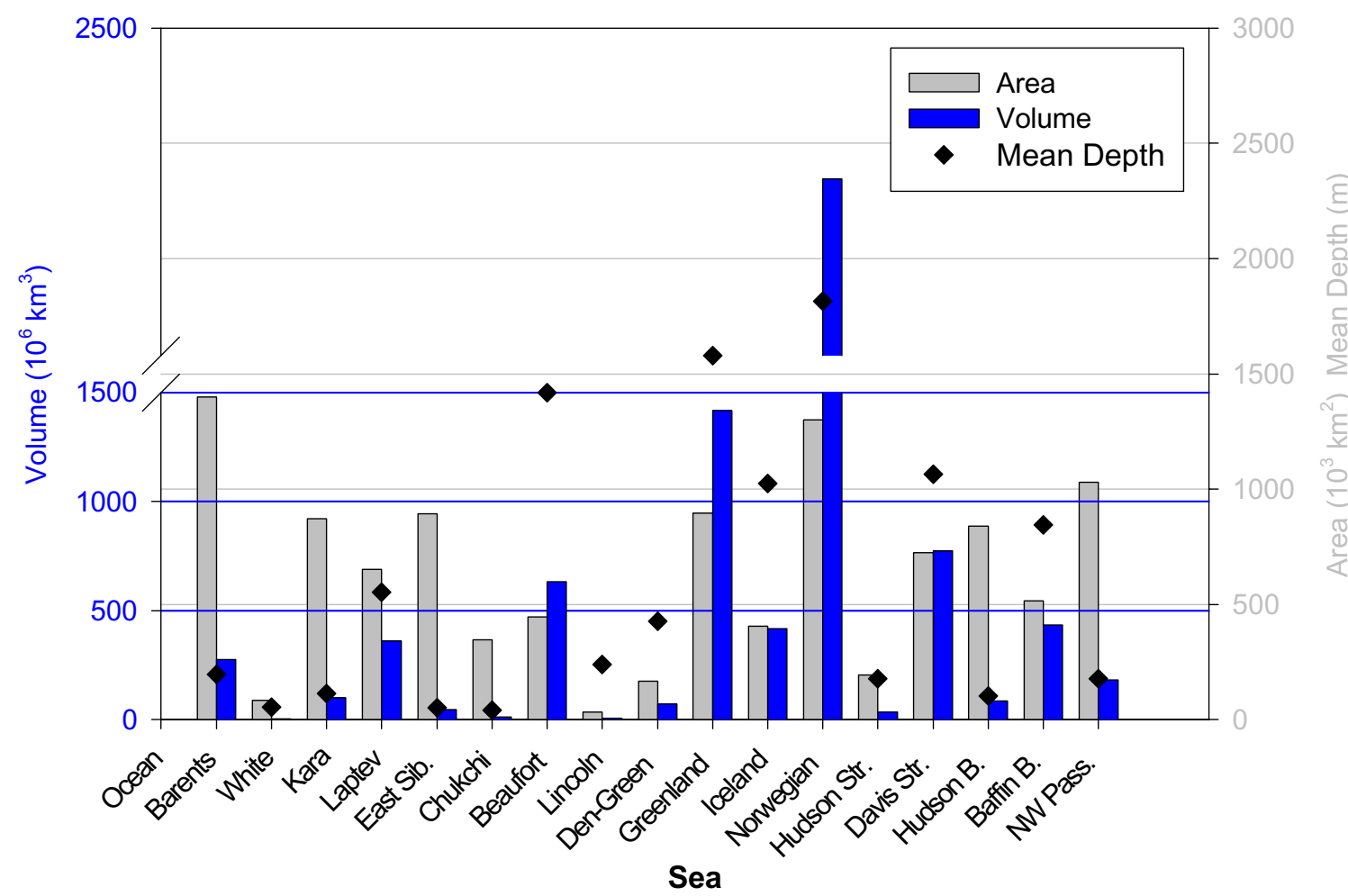

b. Area and volumes of the high Arctic Ocean with redefined limits

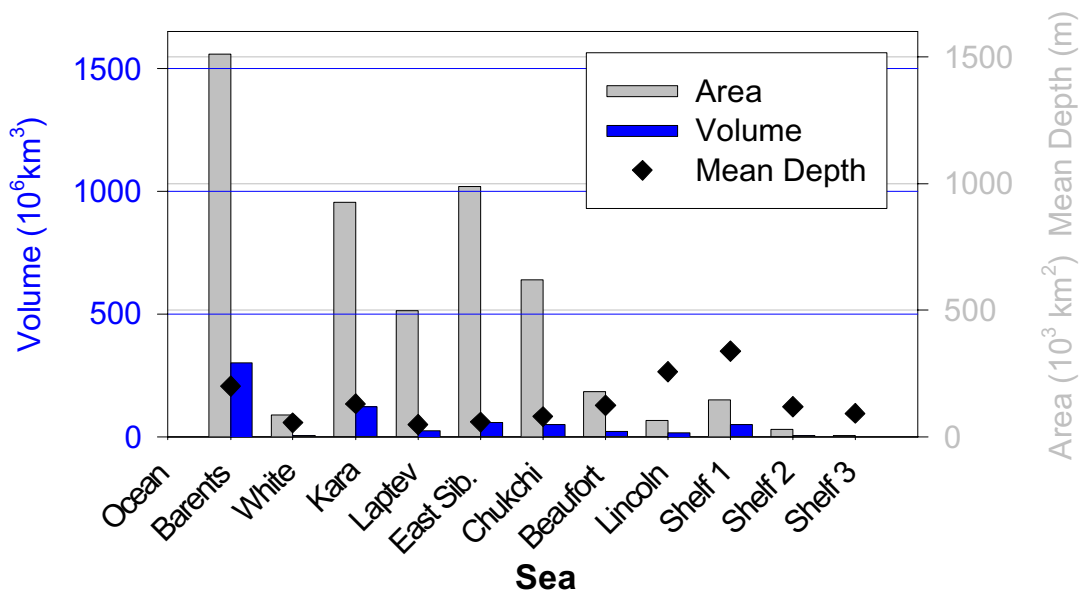

Figure 6. (a) Bar diagram plot of area, volume and mean depth between the IHO-defined Arctic Ocean seas. Table 1 shows the actual values. (b) Bar diagram plot of area, volume and mean depth between the redefined Arctic Ocean seas. Table 2 shows the actual values.

as $\sim 52.9 \%$ of this entire region, which is a significantly larger portion compared with the other world oceans, where the portion from the coasts out to the foot of the continental slopes only ranges between about 9.1 and 17.7\% [Menard and Smith, 1966]. Given this vast shelf area, one must ask whether the circulation pattern in the Arctic is more sensitive to eustatic sea level changes than the 
Table 1. Area, Volume, and Mean Depth of the IHO-Defined Arctic Ocean Constituent Seas ${ }^{\mathrm{a}}$

\begin{tabular}{|c|c|c|c|}
\hline Seas and Oceans & Area, ${ }^{b} 10^{3} \mathrm{~km}^{2}$ & Volume, $10^{3} \mathrm{~km}^{3}$ & Mean Depth, m \\
\hline \multicolumn{4}{|c|}{ IHO-Defined Arctic Ocean } \\
\hline Barents Sea & 1399 & 277 & 198 \\
\hline White Sea & 85 & 5 & 56 \\
\hline Kara Sea & 873 & 100 & 114 \\
\hline Laptev Sea & 54 & 361 & 552 \\
\hline East Siberian Sea & 895 & 46 & 52 \\
\hline Chukchi Sea & 47 & 14 & 41 \\
\hline Beaufort Sea & 447 & 634 & 1420 \\
\hline Lincoln Sea & 32 & 8 & 239 \\
\hline Den./Green. Straits & 168 & 72 & 427 \\
\hline Greenland Sea & 898 & 1418 & 1580 \\
\hline Iceland Sea & 406 & 417 & 1026 \\
\hline Norwegian Sea & 1301 & 2362 & 1816 \\
\hline Hudson Strait & 194 & 35 & 178 \\
\hline Davis Strait & 726 & 774 & 1066 \\
\hline Hudson Bay & 841 & 86 & 103 \\
\hline Baffin Bay & 516 & 436 & 845 \\
\hline Northwestern Pass. & 1032 & 183 & 177 \\
\hline Deep Basin & 4737 & 11,455 & 2418 \\
\hline Totals and mean depth & 15,551 & 18,682 & 1201 \\
\hline \multicolumn{4}{|c|}{ Menard and Smith [1966] } \\
\hline Pacific and adjacent seas & 181,344 & 714,410 & 3940 \\
\hline Atlantic and adjacent seas & 94,314 & 337,210 & 3575 \\
\hline Indian and adjacent seas & 74,118 & 284,608 & 3840 \\
\hline Arctic and adjacent seas ${ }^{c}$ & 12,257 & 13,702 & 1117 \\
\hline All World oceans and seas & 362,033 & $1,349,929$ & 3729 \\
\hline
\end{tabular}

circulation in the other world oceans. Estimates of eustatic sea level during Last Glacial Maximum (LGM) indicate that the sea level was substantially lower than today's, i.e., $\sim 121 \mathrm{~m}$ lower [Fairbanks, 1989] or $\sim 105 \mathrm{~m}$ lower (hydroisostatically corrected) [Guilderson et al., 2000]. Ice sheets covered large portions of the Arctic shelves during LGM, i.e., the Barents Shelf and portions of the Kara Sea shelf [e.g., Svendsen et al., 1999] and portions of Arctic Canada [e.g., Dyke, 1999]. In addition, recent results indicate even more extensive glaciations of the Barents and Kara shelves during Early and Mid-Weichselian as well as perhaps also during the Saalian glacial periods [Svendsen et al., 1999]. This will most probably affect the circulation pattern to a large extent in addition to the lower sea level and other environmental changes during glacial times, such as damming of the Russian rivers, resulting in less fresh water input to the Arctic Ocean [Mangerud et al., 2001] or sea ice extent. However, the results from the analyses of IBCAO bathymetry alone shows that the average depth for all the Arctic Ocean shelf seas, except Barents and Kara Seas and the very small Lincoln Sea and Shelf 1 region, is less than the estimated eustatic sea level drop during LGM (Table 2). In other words, most, if not all, of the Arctic Ocean shelf region could not play a role in the ocean circulation during LGM nor during the Early- and Mid Weichselian glaciations as well as during the Saalian. The Arctic Ocean paleoceanographic conditions have been studied by various methods, and most studies also indicate a significantly different oceanographic environment during glacial times [e.g., Nørgaard-Pedersen et al., 1998; Bischof et al., 1996].

[19] One of the intentions of this work is to provide oceanographers with the most up-to-date volume and area estimations of the Arctic Ocean, which 

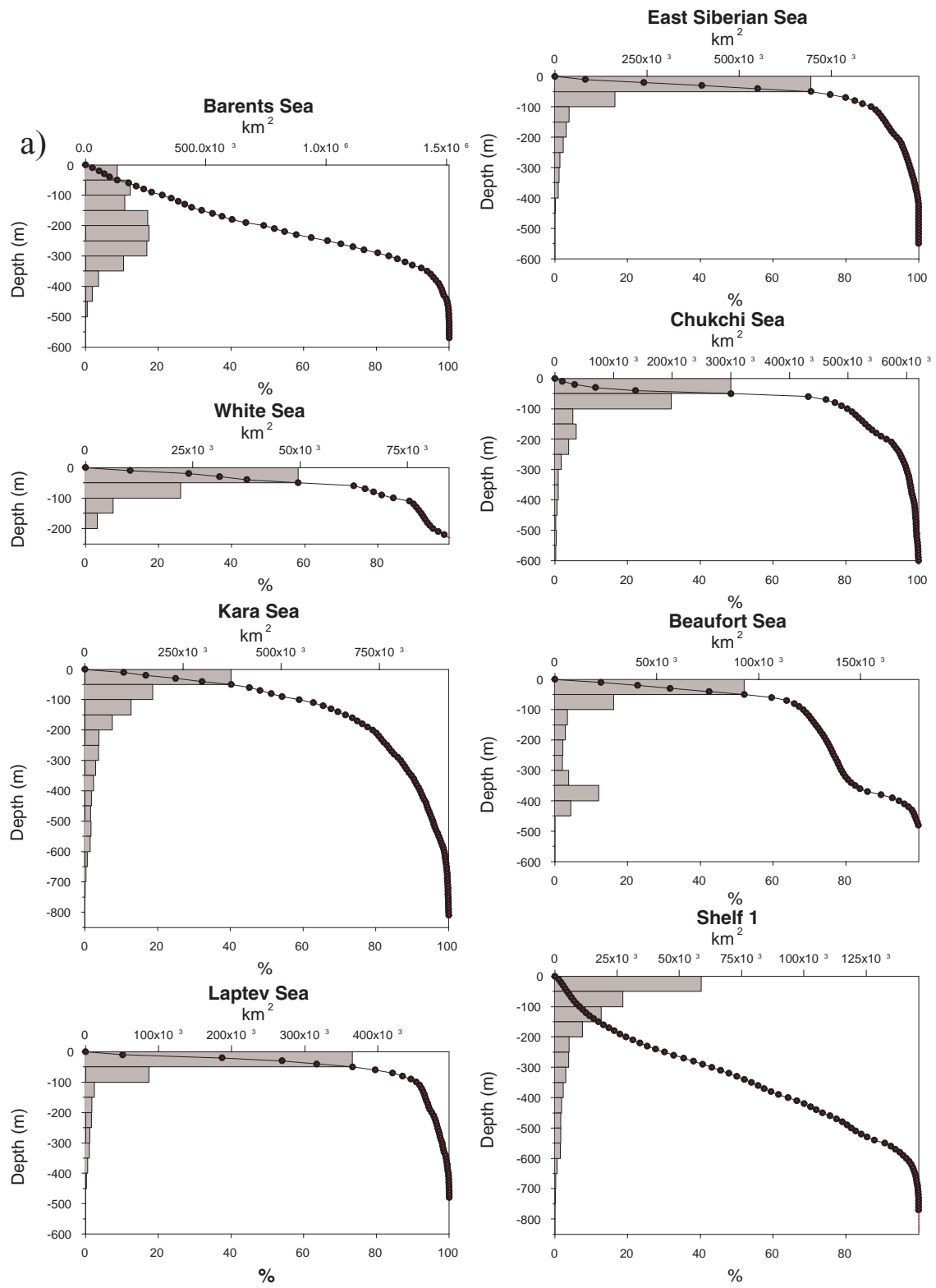

Figure 7. Hypsometry calculated at $50 \mathrm{~m}$ depth intervals (shown as bars) for the Arctic Ocean seas with redefined limits as shown in Figure 2. The plotted curves show the seafloor surface area (in square kilometers on the upper $x$ axis and in accumulative percent on the lower $x$ axis) above the depth indicated on the $y$ axis. This means that each of the defined seas will get the maximum seafloor area at its deepest depth. Observe that the scale on the depth axis is different for the seas with depths exceeding $1500 \mathrm{~m}$.

may be used for modeling experiments or budget calculations. It is possible to derive directly from the supplemental data an estimate of the volume of a simplified body of water that includes a certain depth range and that spans any or more than one of the analyzed regions. For example, Rudels et al. [1994] address the interactions and circulation of waters between 200 and $1700 \mathrm{~m}$, which includes the Atlantic layer and intermediate depth waters in the Arctic Ocean. Figure 8 shows a schematic diagram of the circulation of these waters. The waters in this depth interval are mostly confined to the deep basins, although occasional upwelling onto the deeper shelves may occur [Aagard et al., 1981]. Thus it may be of interest that in the central Arctic Ocean basin the depth between 200 and 

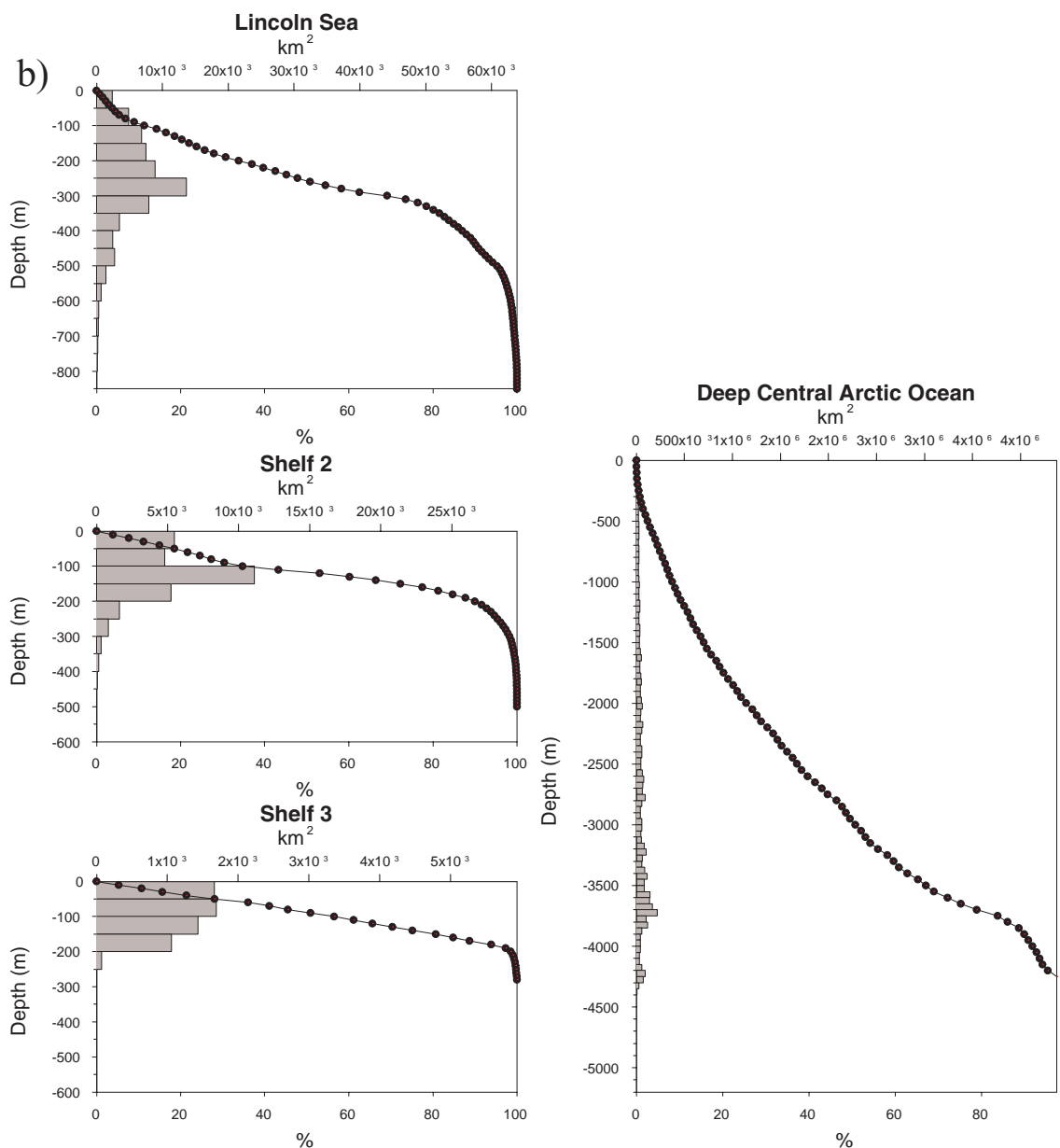

Figure 7. (continued)

$1700 \mathrm{~m}$ reaches a volume of $6173 \times 10^{3} \mathrm{~km}^{3}$, which makes up as much as $50 \%$ of the total volume in the deep basin.

[20] The processes forming the seafloor morphology of the Arctic Ocean shallow continental shelves during the Quaternary involves mainly erosion and deposition from ice sheets, rivers, icebergs, and currents. The hypsometry in glaciated regions has been used as a tool to study glacial erosion compared with erosion caused by tectonic uplift [Brozovic et al., 1997], and hypsometry presented here may give valuable information about the Arctic continental shelf's glaciation history. Studies of the Svalbard-Barents Sea region show that, given a constant precipitation through time, glaciers in this region are vastly more effective as agents of erosion and thus as land/seafloor forming mechanisms than rivers [Elverhøi et al., 1998]. Given this and the glaciation history of the Barents Sea [Svendsen et al., 1999], the shape of hypsometric curve for the Barents Sea presumably derived its main characteristics from ice sheet activity and may be used as a reference from a glaciated portion of the Arctic Ocean continental shelf. The shape of the hypsometric curve (histogram of the frequencies in different $50 \mathrm{~m}$ depth bins) from the East Siberian and Laptev Seas represent the other end-member, and there the glacial history is more controversial. For example, Grosswald and Hughes [1995] suggested that a large ice sheet covered the Laptev and East Siberian seas during the Last Glacial Maximum, with a dome centered just north of the New Siberian Islands, but recent results contradict this reconstruction on the basis of the formation of paleo- 
Table 2. Area, Volume, and Mean Depth in the Arctic Ocean Calculated With Redefined Limits for the Constituent Seas as Shown in Figure $2^{\mathrm{a}}$

\begin{tabular}{lccc}
\hline & Area, $10^{3} \mathrm{~km}^{2}$ & Volume, $10^{3} \mathrm{~km}^{3}$ & Mean Depth, m \\
\hline Barents Sea & 1512 & 302 & 200 \\
White Sea & 85 & 5 & 56 \\
Kara Sea & 926 & 121 & 131 \\
Laptev Sea & 498 & 24 & 48 \\
East Siberian Sea & 987 & 57 & 58 \\
Chukchi Sea & 620 & 50 & 80 \\
Beaufort Sea & 178 & 22 & 124 \\
Lincoln Sea & 64 & 16 & 257 \\
Central Arctic Ocean Basin & 4489 & 12,339 & 2748 \\
Shelf 1 & 146 & 49 & 338 \\
Shelf 2 & 30 & 4 & 119 \\
Shelf 3 & 6 & 1 & 93 \\
Totals and mean depth & 9541 & 12,990 & 1361 \\
& \multicolumn{2}{c}{ Menard and Smith [1966] } & 12,615 \\
Arctic Ocean & 9485 & 1330 \\
\hline
\end{tabular}

\footnotetext{
${ }^{\text {a }}$ The area referred to in this work as the Arctic Ocean confines closely to one of Menard and Smith's two analyzed regions of the Arctic, and thus their results are included for comparison.
}

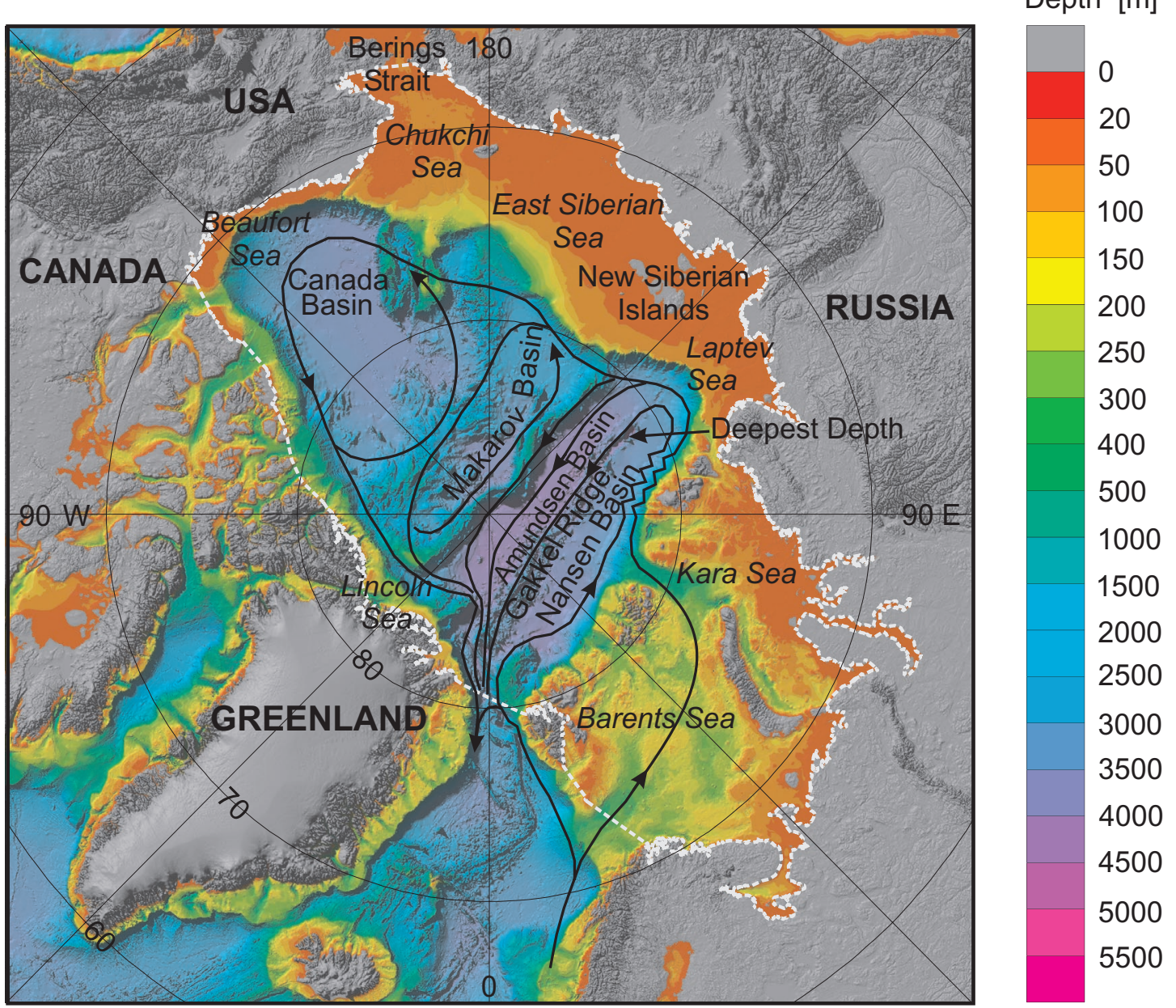

Figure 8. Shaded relief of the IBCAO bathymetry model. The inferred circulation shows the Atlantic layer and intermediate depth waters between 200 and $1700 \mathrm{~m}$ [Rudels et al., 1994]. The white dashed line shows the definition of the Arctic Ocean used in this work. 
river channels and permafrost indicating subaerial exposure of the shelf during LGM and implying absence of ice sheets in this area [Kleiber and Niessen, 1999]. The hypsometry presented here and the overall smooth bathymetry in the IBCAO model would rather support the suggestion that this area has been mainly ice-free. On the other hand, the Lincoln Sea shows some characteristic similarities in shape of the histogram of the frequencies in different $50 \mathrm{~m}$ depth bins to the Barents Sea (Figure 7). In terms of geology and bathymetry the entire North Greenland margin including the Lincoln Sea is the least known of the entire Arctic Basin [Dawes, 1990]. However, the IBCAO bathymetry model is based on enough data in the Lincoln Sea to allow interpretations of the seafloor morphology, and the similarity in hypsometry with the Barents Sea raises the question of extensive glacier ice sheet activity on the Lincoln Sea margin during the Quaternary glaciations.

\section{Acknowledgments}

[21] I am grateful for the constructive comments made on this manuscript by Larry Mayer throughout the preparation process. I would also like to thank Jim Gardner, Ron Macnab, Brian Calder, and two anonymous reviewers for their helpful suggestions to improve the manuscript. Arthur Grantz provided valuable information on the several interpretations of the term Arctic Ocean. Finally, I acknowledge Tony Pharaoh and Michel Huet from the International Hydrographic Bureau for providing me with the draft of the updated document from the International Hydrographic Organization (IHO) containing the limits of the Arctic Ocean and its constituent seas.

\section{References}

Aagard, K., L. K. Coachman, and E. C. Carmack, On the halocline of the Arctic Ocean, Deep Sea Res., 28, 529545, 1981.

Bischof, J., D. L. Clark, and J. S. Vincent, Origin of ice-rafted debris: Pleistocene paleoceanography in the western Arctic Ocean, Paleoceanography, 11, 743-756, 1996.

Brozovic, N., D. W. Burbank, and A. J. Meigs, Climatic limits on landscape development in the northwestern Himalaya, Science, 276, 571-574, 1997.

Dawes, P. R., The North Greenland continental margin, in The Geology of North America, Decade of N. Am. Geol. Ser., edited by A. Grantz et al., pp. 211-226, Geol. Soc. of Am., Boulder, Colo., 1990.
Dyke, A. S., Last Glacial Maximum and deglaciation of Devon Island, Arctic Canada: Support for an Innuitian Ice Sheet, Quat. Sci. Rev., 18, 393-420, 1999.

Elverhøi, A., R. L. B. Hooke, and A. Solheim, Late Cenozoic erosion and sediment yield from the SvalbardBarents Sea region: Implications for Understanding Erosion of Glacierized Basins, Quat. Sci. Rev., 17, 209-241, 1998.

Fairbanks, R. G., A 17,000-year glacio-eustatic sea level record: Influence of glacial melting rates on the Younger Dryas event and deep ocean-circulation, Nature, 342, 637-642, 1989.

Grosswald, M. G., and T. J. Hughes, Paleoglaciology's grand unsolved problem, J. Glaciol., 41(138), 313-332, 1995.

Guilderson, T. P., L. Burckle, S. Hemming, and W. R. Peltier, Late Pleistocene sea level variations derived from the Argentine shelf, Geochem. Geophys. Geosys., 1, 10.1029/2001GC000098, 2000. (Available at http://www. g-cubed.org)

Head Department of Navigation and Oceanography (HDNO) et al., Bottom relief of the Arctic Ocean, scale 1:5,000,000, St. Petersburg, Russia, 1999.

International Hydrographic Organization (IHO), Limits of Ocean and Seas, rep. S-23, draft, 4th ed., Monaco, October 2001.

Jakobsson, M., N. Cherkis, J. Woodward, B. Coakley, and R. Macnab, A new grid of Arctic bathymetry: A significant resource for scientists and mapmakers, EOS Trans. $A G U$, 81(9), pp. 89, 93, 96, 2000.

Jakobsson, M., and IBCAO Editorial Board Members, Improvement to the International Bathymetric Chart of the Arctic Ocean (IBCAO): Updating the Data Base and the Grid Model, EOS Trans. AGU, 82(46), Fall Meet. Suppl., Abstract no. OS11B-0371, 2001.

Kleiber, H. P., and F. Niessen, Late Pleistocene paleoriver channels on the Laptev Sea Shelf: Implications from sub-bottom profiling, in Land-Ocean Systems in the Siberian Arctic: Dynamics and History, edited by H. Kassens et al., pp. 657-665, Springer-Verlag, New York, 1999.

Mangerud, J., V. Astakov, M. Jakobsson, and I. J. Svendsen, Huge Ice dammed lakes in Northern Russia, J. Quat. Res., 16, 773-777, 2001.

Mayer, L. A., C. W. Paton, L. Gee, J. V. Gardner, and C. W. Ware, Interactive 3-D visualization: A tool for seafloor navigation, exploration, and engineering, paper presented at MTS/IEEE Oceans 2000 Conference, Inst. of Electr. and Electron. Eng., Providence, R. I., 11-14 Sept. 2000.

Menard, H. W., and S. M. Smith, Hypsometry of Ocean Basin Provinces, J. Geophys. Res., 71, 4305-4325, 1966.

Nørgaard-Pedersen, N., R. F. Spielhagen, J. Thiede, and H. Kassens, Central Arctic surface ocean environment during the past 80,000 years, Paleoceanography, 13, 193-204, 1998.

Pusharovsky, Y. M., Tectonic map of the Arctic, scale 1:10 000000, Geol. Inst. Akad. Nauk SSSR, Fed. Geod. and Cartogr. Serv. of Russ., Moscow, 1963. 
Rudels, B., E. P. Jones, L. G. Anderson, and G. Kattner, On the intermediate depth waters of the Arctic Ocean, in The Polar Oceans and Their Role in Shaping the Global Environment, Geophys. Monogr. Ser., vol. 85, edited by O. M. Johannessen et al., AGU, Washington, D. C., 1994.

Smith, H. F. W., and D. T. Sandwell, Global seafloor topography from satellite altimetry and ship depth soundings, Science, 277, 1956-1962, 1997.
Soluri, E. A., and V. A. Woodson, World vector shoreline, Int Hydrogr. Rev., LXVII(1), 1990.

Svendsen, J. I., et al., Maximum extent of the Eurasian ice sheets in the Barents and Kara sea region during the Weichselian, Boreas, 28, 234-242, 1999.

Wessel, P., and W. H. F. Smith, Free software helps map and display data, EOS Trans. $A G U, 72(41)$, pp. 441, 445-446, 1991. 